\title{
STUDIES IN THE BORAGINACEAE, XXII NOTEWORTHY SPECIES, CHIEFLY ASIAN AND SOUTH AMERICAN
}

\author{
Ivan M. JoHnston
}

Cordia varronifolia. sp. nov.

Frutex $2 \mathrm{~m}$. alta; ramulis plus minusve villulosis in sicco nigrescentibus; foliis elliptico-oblongis vel ovato-oblongis $4-9 \mathrm{~cm}$. longis $2-4 \mathrm{~cm}$. latis, apice obtusiusculis, basi obtusis rotundisve $2-5 \mathrm{~mm}$. longe petiolatis, margine basim versus excepta saepe crenato-dentatis, supra abundanter minuteque areolato-bullatis setis mollibus brevibus basi bulbosis obsitis, subtus elevate reticulato-venosis griseo-villulosis; cymis paucifloris terminalibus vel rare extra-axillaribus initio glomeratis, posterius in cincinnos solitarios vel rare geminatos $1-2 \mathrm{~cm}$. longos excurrentibus; calyce sub anthesi $15-20 \mathrm{~mm}$. longo griseo-villoso 10 costato, tubo 10-12 $\mathrm{mm}$. longo infra medium crassiore $(4-8 \mathrm{~mm}$. diametro) apice 3-4 mm. diametro basi rotundato, lobis subulatis flexuosis $5-9 \mathrm{~mm}$. longis in alabastro liberis, sinibus obtusis latis; calyce fructifero ad $28 \mathrm{~mm}$. longo, tubo $17 \mathrm{~mm}$. longo $8-9 \mathrm{~mm}$. crasso; corolla alba marcescenti persistente infundibuliformi $3-3.5 \mathrm{~cm}$. longa, limbo $2.5-3.5$ $\mathrm{cm}$. diametro, lobis adscendentibus semi-circularibus $9-11 \mathrm{~mm}$. latis 5-7 mm. longis apice emarginatis, sinibus angustis valde acutis, tubo 2-3 mm. crasso cylindrico ca. $10 \mathrm{~mm}$. longo tubum calycis subaequilongo intus secus bases lineatas decurrentes filamentorum villuloso alibi glabro, fauce ampliata apice ad $12 \mathrm{~mm}$. diametro; filamentis 10-12 mm. longis ca. $10 \mathrm{~mm}$. supra basin tubi corollae orientibus; antheris oblongis ca. $2 \mathrm{~mm}$. longis; ovario glabro $2.5 \mathrm{~mm}$. longo infra medium $1 \mathrm{~mm}$. crasso deinde sursum gradatim attenuato, 4-ovulato 4-loculato imam ad basin nectario annulato inconspicuo circumdato; stylo gracillimo villuloso $15-25 \mathrm{~mm}$. longo $12-20 \mathrm{~mm}$. supra basin furcato, lobis 4 stigmatiferis angustissime oblanceolatis $2-3 \mathrm{~mm}$. longis; fructu exsicco ovoideo calyce persistenti et tubo corollae persistentis investo supra basin 4-5 mm. crasśo deinde sursum angustato (conico, apice rostulato) basi rotundato.

PERU: Pión valley of the Maranon, dept. Cajamarca, prov. Cutervo, 1300$1400 \mathrm{~m}$. alt., shrub $3 \mathrm{~m}$. tall, fl. white, June 1915, A. Weberbauer 7138 (TYPE, Gray Herb.).

This shrub of northern Peru has the areolate-bullate, frequently dentate leaves suggestive of members of Cordia $\S$ Varronia. Its elongate persisting ribbed calyx and the large persisting marcescent funnelform corollas suggest those of members of the section Gerascanthus. Actually, however, this Peruvian plant has close relations only with $C$. parvifolia DC. (C. Greggii Torr.) and C. elaeagnoides DC. of Mexico 
and so constitutes a third member of the section Rhabdocalyx. In size, form and organization of the corolla, calyx and fruit it is most similar to C. parvifolia, a species of the deserts of western and northern Mexico. Like that species, furthermore, its flowers appear to be heterostylic. Its fruits have all the distinctive characteristics of the section Rhabdocalyx. Indeed, the fruit is almost indistinguishable from that of $C$. parvifolia and $C$. elaeagnoides, being conic-ovoid, dry, and nut-like, having similar proportions and dimensions and developing completely ensheathed by the persistent calyx. The endocarp is thin and herbaceous in texture. It is not fleshy nor colored. The fruit is not a drupe. Its bony endocarp has walls about a millimeter thick and is 4-celled and apparently 4-seeded at maturity. This is a fruit very different from that developed by most Cordias and especially by members of the sections Gerascanthus and Varronia, cf. Johnston, Jour. Arnold Arb. 30: 85 (1949) and 31: 179 (1950).

\section{Cordia iguaguana, sp. nov.}

Arbor 8-20 m. alta; ramulis juventate tenuiter inconspicueque fulvotomentulosis, maturitate glabratis; foliis maturitate late lanceolatis $10-15 \mathrm{~cm}$. longis $4-5 \mathrm{~cm}$. latis glabris vel secus costa et petiolo pilulis minutis adpressis sparsissime donatis, apice acutis vel paullo attenuatis, basi obtusis vel rotundis $12-22 \mathrm{~mm}$. longe petiolatis, supra nervis et nervulis abundantibus laeviter impressis ornatis, subtus pallidioribus nerviis (utrinque costae 5-7) et costa prominulis donatis; inflorescentia apice ramulorum hornotinorum foliis juvenilibus gestorum prodita multiflora paniculata vel corymbosa $12-15 \mathrm{~mm}$. diametro; calyce clavatocylindraceo ca. $11 \mathrm{~mm}$. longo (apicem versus ad $3 \mathrm{~mm}$. crasso) prominenter 10-costato, extus inconspicue puberulento saepe pilulis sparsis ad $0.2 \mathrm{~mm}$. longis adpressis sparse donatis, costis saepe evidenter longitudinaliterque sulcatis, lobis $3-5$ saepe inaequalibus obtusis triangularibus ca. $1 \mathrm{~mm}$. longis, sinibus obtusis; corolla alba $23 \mathrm{~mm}$. longa extus glaberrima, limbo ca. $25 \mathrm{~mm}$. diametro, lobis $6-8 \mathrm{~mm}$. longis $8-10 \mathrm{~mm}$. latis supra basin latioribus rotundis vel apice plus minusve truncatis non rariter emarginatis, sinibus angustis acutis, tubo $8-8.5 \mathrm{~mm}$. longo 1-1.5 mm. crasso intus infra medium tomentuloso, faucibus $12-15 \mathrm{~mm}$. diametro ca. $5 \mathrm{~mm}$. profundis, filamentis glabris ore tubi (8-9 supra basin tubi) affixis inaequalibus $1-3 \mathrm{~mm}$. longis, antheris $1.5-3 \mathrm{~mm}$. longis inaequalibus; pistillo (ovario cum stylo) glabro $13-14 \mathrm{~mm}$. longo basi angusta nectario destituto ca. $10 \mathrm{~mm}$. supra basin furcato parte ovuliferi fusiforma $1-1.5 \mathrm{~mm}$. supra basin $0.8-1.2 \mathrm{~mm}$. crasso deinde sursum in stylum gradatim transmutato; fructu ignoto.

PERU: Jaen, dept. Cajamarca, prov. Jean, 700-800 m. alt., tree 8-20 m. tall, fl. white, "Iguaguana," April 1912, A. Weberbauer 6213 (түрE, Gray Herb.).

A very well marked species of northwestern Peru, apparently restricted to the seasonally dry interandean valleys of the upper Marañon drainage, cf. Weberbauer, Bot. Jahrb. 50: 92-3 (1914). The tree is 
locally known as "iguaguana." It is a member of the section Gerascanthus. Only three other species of this section are known from western South America. The best known is the widely distributed and variable $C$. alliodora (R.\& P.) Oken, which is readily distinguished by its indument of stellate hairs and by the swellings on twigs and in the inflorescence which serve as ant-domatia. The other members of the section in the area have simple hairs only and are not myrmecophilous. All three are local in distribution and very distinct and easily distinguished. Cordia Goeldiana Huber, formerly known only from the state of Para, Brazil, has been recently found in northern Colombia (Pivijay, dept. Magdalena, 1948, R. Romero Castañeda 1106). It has elongate oblong corolla-lobes which have parallel lateral margins. Cordia macrantha Chodat is a rare tree of western Ecuador, cf. Little, Caribbean Forester 9: 269 (1948). Like $C$. iguaguana it has broad rounded corolla-lobes. It differs from the Peruvian species in its larger elliptic leaves scantily though evidently villose-hispidulous on the lower surface. Its flowers are also much larger. The corolla is $35-43 \mathrm{~mm}$. long, the limb is $35-40 \mathrm{~mm}$. in diameter, and the sinus between the lobes are truncate rather than acute. The corolla is glabrous except for a tuft of hairs at the base of each filament. The ovary, unlike that of $C$. iguaguana, is short and broad. It is surrounded at the base by a well-developed collar-like nectary, and has the style arising abruptly from its broad summit. The evidence available indicates that $C$. macrantha and $C$. iguaguana are both heterostylic. The type of the latter is probably the long-style form of the species.

Cordia viridis (Rusby), comb. nov.

Bourreria viridis Rusby, Descr. 300 So. Amer. Pl. 100 (1920).

VENEZUELA: Lower Orinoco, 1896, Rusby \& Squires 259 (AA, IsотyPe) ; Guayapo, Bajo Caura, Bolivar, 100 m. alt., 1939, L. Williams 11745 (G); El Toro, La Paragua, Bolivar, 70 m. alt., 1940, Williams 12699 (G).

A species of the lower Orinoco Valley which has been confused with C. sericicalyx DC. It is readily distinguished once its characters are recognized. The fruit is much larger and is elongate and arises erect, not obliquely from the calyx. Its leaves, though having a similar sparse minute strigosity, differ from those of $C$. sericicalyx in their more acuminate apex and more numerous (about 10) pairs of primary veins.

Cordia Bridgesii (Friesen), comb. nov.

Varronia Bridgesi Friesen, Bull. Soc. Bot. Genève ser. 2, 24: 172, f. 9 (1933).

BOLIVIA: Rio Caine, Cochabamba, $1180 \mathrm{~m}$. alt., sandy soil, shrub $3-5 \mathrm{dm}$. tall, fl. white, Jan. 1949, M. Cardenas 4239 (G).

The above cited collection agrees with the original description and illustration in all significant details. The only exception is the shorter apical appendages on the calyx-lobes. The original description calls for free appendages $2 \mathrm{~mm}$. long. The collection made by Cardenas has free appendicular tips $0.2-0.5 \mathrm{~mm}$. long. The species is a very well 
marked one and was based on a specimen unprovided with precise locality data, collected by Thomas Bridges in Bolivia in 1844 or 45, probably during his journeys north and east of Cochabamba. It was accordingly obtained in the general area where Cardenas also found it.

Cordia lutea Lam. Ill. 1: 421 (1791) ; Svenson, Am. Jour. Bot. 33: 421 and 478 (1946).

Cordia marchionica Drake, Ill. Fl. Ins. Pacific 240 (1892) and Fl. Polynése Fr. 129 (1893) ; F. B. H. Brown, [Fl. Southeast. Polynesia 3:] Bull. Bishop Mus. 130: 243 (1935), — based on material from "Iles Marquises (Mercier!, Jardin 54!)."

MARQUESAS ISLANDS: Uahuka, 1921-22, E. H. Quale 1737 (A) ; Hatutu, shrub on windward cliff, Sept. 27, 1922, Quale 1556 (A).

It has been a surprise to discover that Cordia marchionica of the Marquesas is the same as the well-known and very distinct $C$. lutea of the Galapagos Islands and the adjacent drier portions of western Ecuador and northwestern Peru. Brown in his detailed account of the flora of southeastern Polynesia reports the plant from most of the islands in the Marquesas group and states that it is common there in dry exposed situations below $1000 \mathrm{~m}$. alt., in places forming thickets or even becoming one of the dominant woody plants.

With the recognition of the Marquesas plant as identical with $C$. lutea of western South America the question arises as to the origin of the species in the archipelago. As a Polynesian plant with clear American relationships it can be used by those seeking evidence of direct floristic affinities between Polynesia and America, cf. A. M. Adamson, Bull. Bishop Mus. 139: 31 (1936). It is conceivable that birds may have played a role in the spread of the species within the Marquesas, but considering the large size of its drupe, any suggestion of direct birdtransportation from America would be fantastic. That the species reached the Marquesas from America in ocean-drift seems equally unlikely. This Cordia is not a strand plant. It is a shrub or small tree of arid situations inland where the rainfall is not only scant but also limited to a very few months each year. The seeds of such plants must germinate promptly when moisture becomes available if the seedling is to become established during the short rainy season. Their seeds and any sheathing part of the fruit are necessarily permeable by water and accordingly unadapted for immersion in sea-water and so for successful ocean dispersal. Furthermore, a recent analysis of ocean-dispersed strand plants (Johnston, Sargentia 8: 55, 1949) indicates that with very few exceptions such plants have been unsuccessful in colonization across the expanse of the eastern Pacific. It is unbelievable that this Cordia could succeed where so many better adapted plants have failed. Any theory that Polynesians may have contributed to its presence in the archipelago is untenable. The plant is said to be used only in making leis, scarcely an important economic use and hardly one to make it important to the native inhabitants. An aboriginal introduc- 
tion of the plant from America might be expected only by way of Easter Island, that lonely outlier of Polynesia in the eastern Pacific. Although the environment of Easter Island would seem even more suitable for the Cordia than the Marquesas, the plant is absent there. I believe that it is significant that this Cordia was not found in the Marquesas by the early visitors to the islands. With its great abundance of large yellow flowers it is a plant not easily overlooked. I am willing to believe that the species was introduced into the Marquesas by the French during the 19th Century, probably as an ornamental plant.

\section{Eritrichium laxum, sp. nov.}

Perenne humile dense caespitosis griseum pilis $0.2-0.8 \mathrm{~mm}$. longis saepe adpressis haud abundantibus vestitum; caulibus hornotinis floriferis debilibus gracillimis erectis vel plus minusve decumbentibus 1-6 (in statu fructifero rare ad 12 ) $\mathrm{cm}$. longis; foliis hornotinis inferioribus $1.5-4 \mathrm{~cm}$. longis spathulato-oblanceolatis $3-5 \mathrm{~mm}$. latis sub apicem rotundum obtusumve latioribus deinde deorsum in petiolum gracilem anguste alatum gradatim attenuatis, subtus costatis sed enervatis; foliis superioribus paucis ad $1 \mathrm{~cm}$. longis; foliis annotinis desiccatis plus minusve persistentibus saepe (praesertim petiolis) spiraliter tortuosis; inflorescentia laxiflora subracemiformi bracteis foliaceis paucis pedicellos haud suffulcientibus praedita; pedicellis sub anthesi $1-5 \mathrm{~mm}$. longis vel eis medium versus vel infra medium caulis orientibus 5-15 $\mathrm{mm}$. longis; pedicellis fructiferis $5-20 \mathrm{~mm}$. longis gracillimis adscendentibus vel laxe recurvatis; lobis calycis anguste oblongis vel oblanceooblongis sparse strigosis ecostatis apice rotundis sub anthesi $1-1.5 \mathrm{~mm}$. longis $0.4-0.5 \mathrm{~mm}$. latis, maturitate ad $2 \mathrm{~mm}$. longis et $0.5-0.6 \mathrm{~mm}$. latis; corolla alba vel dilute caerulea medium versus flava $5-6 \mathrm{~mm}$. diametro; lobis patentibus rotundis ca. $2.2 \mathrm{~mm}$. longis et $2 \mathrm{~mm}$. latis, tubo $1.3-1.7 \mathrm{~mm}$. longo a basi $0.3-0.5 \mathrm{~mm}$. crasso sursum ampliato apice $1.5-1.7 \mathrm{~mm}$. diametro intus $0.2-0.3 \mathrm{~mm}$. supra basin nectario lineato inconspicuo glabro donato, appendiculis faucium flavis vix prominentibus; filamentis $0.15 \mathrm{~mm}$. longis ca. $0.7 \mathrm{~mm}$. supra basin tubi corollae affixis, antheris $0.3 \mathrm{~mm}$. longis; ovario 4-lobato glabro; stylo sub anthesi $0.4-0.5 \mathrm{~mm}$. longo tempore fructifero persistenti $0.5-0.7$ $\mathrm{mm}$. longo; nuculis a gynobase hemispherica divergentibus dorsi-ventraliter compressis evidenter marginatis, sine margine $1.2-1.7 \mathrm{~mm}$. longis $0.8-1 \mathrm{~mm}$. latis, dorse obovatis plus minusve hispidulis, margine aculeos $0.3-0.6 \mathrm{~mm}$. longos saepe adscendentes triangulares longe attenuatos apice glochidiatos composito saepissime circumdatis, facie ventrali glabris vel praesertim ultra medium muriculatis aliquantulum ultra medium cicatrice parva donatis ultra cicatricem usque ad apicem nuculi carina $0.3-0.4 \mathrm{~mm}$. longa donatis alibi convexis.

TIBET: Tse La, Langong, lat. $28^{\circ} 45^{\prime}$, long. $94^{\circ} 00^{\prime}$, $14500 \mathrm{ft}$. alt., little tufts in dry cliff crevices, corolla creamy white, eye golden, very fragrant, F. Ludlow, G. Sherriff \& G. Taylor 5619 (TYPE, Gray Herb.); hills north of 
Lhasa, $15000 \mathrm{ft}$., clumps under large boulders, fl. pale blue with yellow eye, Ludlow \& Sherriff 8806 (G); hills north of Lhasa, $14000 \mathrm{ft}$., under cliffs and rocks, fl. white to pale blue, Ludlow \& Sherriff 9704 (G) ; Nyenchengtang La, 4 days N. W. of Lhasa, $14000 \mathrm{ft}$., on grassy cliff-ledges and under rocks, fl. pale blue, Ludlow \& Sherriff $9648(\mathrm{G})$.

CHINA: Chungtien Plateau, N. W. Yunnan, plant 1 in. high, on open stony slope, K. M. Feng $1598(\mathrm{G})$; Riutzila, one day from Atuntze, mountains of Moying, northeast of Yangtze-Mekong watershed, N. W. Yunnan, flower yellow, J. F. Rock 10332 (G); Kon-ka-ling, Sikang, T. T. Y u 13005 (G); Kansu, high rocks, 12-13,000 ft., Aug. 1914, R. Farrer 634 (G).

A very well marked species of southeastern Tibet and adjoining western China where it appears to be the only representative of the genus. From a weak taproot and abundant fibrous roots the plant develops crowded short branched stems abundantly clothed with persisting remnants of old leaves. These hug the soil and form a very dense low cushiony growth which may become at least a decimeter in diameter. From it arise the functional basal leaves and the weak sparingly leafy fertile branches. The herbage is green or grayish green and not silvery silky as with most other species of the genus. The fruit is especially distinctive. The nutlets are dorsi-ventrally compressed and proportionately not so thick as those of other congeners. Furthermore, they have an attachment scar that is slightly, but still very clearly supramedial, rather than medial or inframedial. As a result they have a shorter ventral keel and the under face is low convex rather than boat-shaped or frustum-like. The only fully ripe nutlets studied are those of the type-collection and these were detached and found adherent to the foliage. Most of them have triangular marginal appendages of the type described, but a few have only a thickened marginal rim bearing a few reduced strongly inflexed (not spreading) appendages. This latter type of nutlet possibly may be produced from cleistogamic flowers at the base of the stems, as in Actinocarya (cf. Johnston, Jour. Arnold Arb. 21: 52. 1940) or be the odd nutlet in a heteromomrphic fruit. The precise condition can be determined only when specimens in prime fruiting state become available for study.

Eritrichium elongatum Wight var. Paysoni, var. nov.

A forma genuina differt radice gracillima apice caules rosulasque foliorum perpaucas emittenti, innovationibus ut videtur biennis et post tempus fructiferum deciduis; caulibus fertilibus e rosulis foliorum annotinis erumpentibus $2-12 \mathrm{~cm}$. altis rigidis erectis cymas terminales et laterales proferentibus; corolla $2-2.5 \mathrm{~mm}$. diametro; nuculis margine evidenter dentato donatis.

UTAH: La Motte Peak, Uinta Mts., Summit Co., alpine meadows, $11500 \mathrm{ft}$,, July 19, 1916, E. B \& L. B. Payson 5039 (G) ; Henry Forks Basin, Uinta Mts., Summit Co., stony slopes and ridges of open forks in upper tree zone above Henry Forks Lake, plants 2-10 (-12) cm. tall, 10850 ft. alt., Aug. 4, 1936, Bassett Maguire, Dean Hobson, \& Ruth Maguire 14385 (TYPE, Gray Herb.); Upper Henry Forks Basin, in stony soil north of Lake Blanchard, common 
above timber-line, $11200 \mathrm{ft}$. alt., plant 3-10 (-12) cm. tall, Aug. 4, 1936, Maguire, Hobson \& Maguire 14346 (G) ; Krebs Basin, Uinta Mts., Duchesne Co., $11400 \mathrm{ft}$. alt., southeast slopes, alpine tundra near first of the upper lakes, July 19, 1933, F J. Hermann 5038 (G); Uinta Mts., 12000 ft., Aug. 1869, S. Watson 849 (G)

Over twenty-five years ago I received a collection of the present plant from the late Edwin Payson, who wrote me at the time that having observed it in the field he believed it to be very different from the Eritrichium elongatum with which he was familiar in the mountains of Wyoming and Colorado. Despite Payson's belief that an undescribed species was involved, his plant was put away as one of the many minor forms of E. elongatum. Subsequently other obviously similar plants have been received. These all came from the Uinta Mts. of northeastern Utah, where no other representative of the genus is known. They all have relatively stout erect branched fertile stems and all appear to be relatively short-lived plants that never develop the woody caudex or achieve the dense pulvinate growth-form of usual E. elongatum. I suspect that the plants may live only a few years, probably only two or three. In any case the stems, along with the leaves of the rosette that clothe their base, all die back to the ground after the fruit is matured. There is accordingly no great accumulation of old leaves as in E. elongatum. The leafy mass at the base of the plant becomes only $1-5 \mathrm{~cm}$. broad. The nutlets always have a dentate margin and are accordingly unlike the unarmed nutlets of the most common and widely distributed forms of E. elongatum. They are, however, very similar, in fact indistinguishable from those of the uncommon form of E. elongatum, the var. argenteum. The plant of the Uinta Mountains may possibly merit specific rank, but pending further observations by those who can study it in the field it seems best to treat it as a very well marked geographic variety. The name of Edwin Payson is properly associated with it.

\section{Trigonotis ciliolata, sp. nov.}

Herba repens; caulibus elongatis $1-1.5 \mathrm{~mm}$. crassis hispidulis pilis divaricatis $0.5-1.2 \mathrm{~mm}$. longis donatis; foliis alternis ovatis $15-22 \mathrm{~mm}$. longis $8-16 \mathrm{~mm}$. latis utrinque pilis $0.5-1 \mathrm{~mm}$. longis rigidulis (in facie superiore laminae adscendentibus, in facie inferiore adscendentibus et erectis) e basi pustulata orientibus obsitis, apice obtusis apiculatis, basi obtusis asymmetricis in petiolum 1-2 mm. latum $2-5 \mathrm{~mm}$. longum abrupte contractis; floribus caulinis solitariis extra-axillaribus saepe circa insertione petioli orientibus tempore anthesi $2-3 \mathrm{~mm}$. longe pedicellatis, maturitate $10-15 \mathrm{~mm}$. longe pedicellatis; sepalis lanceolatis sub anthesi $4 \mathrm{~mm}$. longis supra basin $1-1.5 \mathrm{~mm}$. latis, maturitate ad $4.5 \mathrm{~mm}$. longis et $1.5-2 \mathrm{~mm}$. latis, sparse hispidulis, apice acutis vel paullo attenuatis; corolla alba, lobis orbicularibus $3-4 \mathrm{~mm}$. diametro; tubo $2.2 \mathrm{~mm}$. longis a basi ca. $1.5 \mathrm{~mm}$. crassa sursum ampliato apice ad $2.8 \mathrm{~mm}$. diametro, appendiculis faucium trapeziformibus prominulis 
puberulentis, filamentis $0.4 \mathrm{~mm}$. longis medio tubi corollae orientibus, antheris $0.7-0.8 \mathrm{~mm}$. longis oblongis infra medium affixis; stylo maturitate ad $1.3 \mathrm{~mm}$. longo apices nuculorum vix superanti; nuculus 4 tetrahedraeis nigris laevibus subnitidis angulatis, angulo adaxillari ca. $1 \mathrm{~mm}$. longo, faciebus 3 inferioribus subaequalibus planis; facie superiore nuculae convexa triangulari ca. $2 \mathrm{~mm}$. longa et lata, marginibus ciliolatis (pilulis $0.1 \mathrm{~mm}$. longis) eis lateralibus valde acutis, margine abaxillari anguste alato (ala adscendente curvata $0.2-0.3 \mathrm{~mm}$. lata).

DUTCH NEW GUINEA: Angi, creeping on sandy bank along Iray River, Lake Giji, Arfak Mts., 1900 m. alt., fl. white, April 8, 1940, R. Kanehira \& S. Hatusima 13883 (TYPE, Arn. Arb.).

Though very different in fruit, the present plant simulates T. abata very closely in gross habit and vegetative characters and is probably most closely related to it. It comes from western Dutch New Guinea about $600 \mathrm{~km}$. northwesterly from the high mountain valleys, near Lake Habbema, where T. abata Johnston (1940) has been collected. The completely glabrous nutlets of $T$. abata are bifacial, having a large convex back, a broadly angled adaxial face, and a superbasal attachment. The very angulate nutlets of $T$. ciliolata are tetrahedral and bear their attachment at the peak of the equally three-sided pyramid. Their fourth surface, the uppermost and outer one, is also triangular but differs in being convex. Its abaxial edge bears an up-curving knifelike wing. Its lateral edges are merely sharply acute. All three of its edges are ciliolate, a unique development in the genus. Unlike most of the repent Malaysian species of Trigonotis, T. ciliolata has distinctly tetrahedral nutlets generally similar in type to those prevailing in the genus in other regions. Its discovery lends additional support to the belief that the Malaysian species, formerly segregated as Zoelleria and Havilandia, are, indeed, merely aberrant members of the present genus, cf. Johnston, Jour. Arnold Arb. 21: 58 (1940).

\section{Trigonotis cupulifera, sp. nov.}

Herba 1-2 dm. alta sparse strigosa (pilis rectis 0.1-0.5 mm. longis antrorsis) ; caulibus gracilibus erectis subsimplicibus $1-1.5 \mathrm{~mm}$. crassis; foliis firmiusculis ovatis vel ellipticis sparse strigosis $1-2.5 \mathrm{~cm}$. longis 8-12 mm. latis, basi saepe rotundis obtusisve in petiolum abrupte contractis, apice rare acutis plerumque rotundis obtusisve et saepe minute apiculatis; petiolo folii inferiori $1-2 \mathrm{~cm}$. longo folii superiori $2-10 \mathrm{~mm}$. longo; cymis solitariis caulem terminatis et axillis foliorum supremis orientibus gracillimis ebracteatis maturitate ad $8 \mathrm{~cm}$. longis laxifloris; sepalis sparse strigosis sub anthesi $1-1.3 \mathrm{~mm}$. longis $0.6-$ $0.7 \mathrm{~mm}$. latis acutis ovato-lanceolatis, maturitate ovatis patentibus $2-2.5 \mathrm{~mm}$. longis ad $1.3 \mathrm{~mm}$. latis, $0-3 \mathrm{~mm}$. longe pedicellatis; corolla caerulea, limbo ca. $4 \mathrm{~mm}$. diametro, lobis rotundis ca. $1 \mathrm{~mm}$. latis, tubo cylindrico $1 \mathrm{~mm}$. longo $1.3 \mathrm{~mm}$. crasso; staminibus medio tubi affixis; nuculis valde angulatis laevibus glabris tetrahedraeis nitidis 0.8-1 mm. longis, basi haud pedicellatis, facie superiori evidenter 
marginatis, margine opaco erecto crassiusculo $0.3-0.6 \mathrm{~mm}$. alto cupulum formanti.

KIANGSI: Lin-chuan, $105 \mathrm{~m}$. alt., by river, fl. white, June 20, 1932, Y. Tsiang 9931 (TYPE, Gray Herb.).

HUNAN: Changsha, along Linyang-ho, $35 \mathrm{~m}$. alt., in thickets, April 25, 1918, Handel-Mazzetti 11687 (G).

The collection from Changsha, cited above, is the basis for recent reports of $T$. brevipes Maxim. from China, cf. Hand.-Mazz. Symb. Sin. $7^{2}: 820$ (1936) and Johnston, Jour. Arnold Arb. 18: 6 (1937). It consists of plants in flowering state which simulate the Japanese plants closely in vegetative characters and general aspect. The resemblance, however, proves to be deceptive. Now that fruit of the Chinese plant is available for study it is obvious that any resemblances between the Chinese and Japanese plants is superficial and inconsequential. The two differ so widely in nutlets that direct relation between them is unbelievable.

The nutlet of $T$. cupulifera has a smooth, lustrous, acutely angled, distinctly tetrahedral body which is $0.8-1 \mathrm{~mm}$. in length along the inner angle. The total nutlet, however, is actually longer, for its upper face is bordered by an upturned erect thickish marginal flange 0.3$0.6 \mathrm{~mm}$. high. The outer faces of this flange are in the same plane as the flat sides of the nutlet body directly beneath and may appear at first sight to be a continuation of them. Nutlet body and flange, however, are readily distinguished by close examination, since the former has a lustrous and the latter an opaque surface. The shallowly cupshaped superstructure on the nutlet body is a distinctive feature of our present species.

Trigonotis floribunda, sp. nov.

Planta herbacea fortasse rhizomate gracillimo oriens; ramis gracilibus laxe decumbentibus $1-5 \mathrm{dm}$. longis $1-2.5 \mathrm{~mm}$. crassis saepe laxe longeque ramosis sparse antrorseque strigosis (pilis $0.2-0.8 \mathrm{~mm}$. longis) ; foliis numerosis caulinis ellipticis vel elliptico-ovatis vel ovato-lanceolatis 2-6 (saepe 3-4) cm. longis 8-27 (saepe 10-20) mm. latis superioribus quam inferioribus saepe duplo vel triplo minoribus, saepe apiculatis costatis sed obscurissime nervatis, apice acutis vel obtusis rotundisve, basi obtusis vel rotundis in petiolum $3-18 \mathrm{~mm}$. longum alatum ca. $1 \mathrm{~mm}$. latum abrupte contractis, facie superiore pilis sparsis 0.3-1.2 $\mathrm{mm}$. longis adpressis vel adscendentibus non rare basi bulbosa vel disciforma orientibus obsitis, facie inferiore antrorse strigosis; cymis numerosis ebracteatis simplicibus vel furcatis $0-5 \mathrm{~cm}$. longe pedunculatis terminalibus et axillis foliorum superiorum orientibus maturitate $5-15 \mathrm{~cm}$. longis dissitifloris; calyce sub anthesi $1.5 \mathrm{~mm}$. longo $0-1 \mathrm{~mm}$. longe pedicellato, lobis oblongis vel elliptico-obovatis $1-1.2 \mathrm{~mm}$. longis, $0.2-0.4 \mathrm{~mm}$. latis; calyce fructifero $2-3 \mathrm{~mm}$. longo 2-3 mm. longe graciliterque pedicellato basi incrassato plus minusve pallido, tubo cupulato, lobis adscendentibus $1.5-2.5 \mathrm{~mm}$. longis ob- 
lanceolatis $0.2-0.6 \mathrm{~mm}$. latis basin versus angustatis apice obtusis; corolla caerulescente $2-2.5 \mathrm{~mm}$. diametro, tubo $1 \mathrm{~mm}$. longo cylindrico $1.2 \mathrm{~mm}$. crasso, limbo ad $2 \mathrm{~mm}$. diametro, lobis rotundis $0.7-$ $0.9 \mathrm{~mm}$. longis; staminibus paullo supra medium tubi corollae affixis; nuculis 4 angulatis tetrahedraeis laevibus glabris nullo modo pedicellatis, angulo adaxillari $1 \mathrm{~mm}$. longis, angulo facies superiorem aliquantulum concavam circumdato acutissimo prominulis, apice nuculis inconspicue producto et sursum curvato.

WESTERN SZECHUAN: Mt. Omei, Fu-hu-sse, roadside, $3 \mathrm{dm}$. tall, fl. blue, May 14, 1942, W. P. Fang 187 47 (G) ; Mt. Omei, Tru-dien, May 28, 1941, Fang 16747 (G) ; Mt. Omei, Hong-train-ping, $35 \mathrm{~cm}$. tall, May 21, 1940, C. L. Sun 2124 (G) ; Mt. Omei, Hong-train-ping, fl. blue, July 8, 1940, T. C. Lee 2704 (G) ; Mt. Omei Hung-chun-ping, roadside, $950 \mathrm{~m}$. alt., June 16, 1938, H. C. Chow 7532 (G) ; Mt. Omei, Hung-chun-ping, roadside, May 22, 1944, H. C. Chow 11851 (G); Mt. Omei, Kuan-hsin-an, ditch, fl. bluish, 1378 m., July 17, 1939, S. C. Sun \& K. Chang 877 (тype, Gray Herb.) ; Mt. Omei, $950 \mathrm{~m}$. alt., about thicket, fl. bluish, July 1, 1931, F. T. Wang 23129 (G) ; Mt. Omei, 850 m., hillside, plant 2.5 dm. tall, fl. blue, July 18, 1938, T. C. Peng 17 (G); without locality, Faber 598 (NY).

KWANGSI: Nan Kan, Ling Yü Hsien, valley shade, fl. bluish, Apr. 13, 1933, Steward \& Cheo 184 (G).

This plant, and also $T$. laxa, were incorrectly identified as $T$. omeiensis Matsuda (1919), in my synopsis of the Trigonotis of southern China, Jour. Arnold Arb. 18: 6 (1937). Matsuda's species properly belongs in the synonymy of the very different T. Cavaleriei (Lev.) Hand.-Mazz. Our present plant is without a name. Its closest relative is T. laxa. Among its distinctive features are the up-curving corners of the upper face of the nutlet and the mineralized pallid epidermis developed on the thickened base of old fruiting calyces.

Trigonotis laxa, sp. nov.

Herba ut videtur perennis; caulibus $2-5 \mathrm{dm}$. longis $1-2.5 \mathrm{~mm}$. crassis simplicibus vel sparse ramosis sparse strigosis; foliis caulinis costatis sed enervatis, lamina elliptica vel ovato-elliptica vel late lanceolata saepe $2-3 \mathrm{~cm}$. longa et $6-15 \mathrm{~mm}$. lata, apice obtusa vel rotunda et apiculata vel rare acuta, basi obtusa rotundave in petiolum 3-10 mm. longum alatum 1-2 mm. latum contracta, supra glabra vel apicem versus sparse strigosa, subtus sparse strigosa (pilis $0.2-0.5 \mathrm{~mm}$. longis non rare basi incrassata disciformave orientibus); inflorescentia terminali et axillis supremis orientibus; cymis gracillimis ad $1 \mathrm{dm}$. longis furcatis 1-8 mm. longe pedunculatis ebracteatis; corolla subcaerulea vel subalba, limbo $5 \mathrm{~mm}$. diametro, lobis rotundis $1.5 \mathrm{~mm}$. latis, tubo 1-1.5 mm. longo a basi ca. $1 \mathrm{~mm}$. crasso sursum gradatim ampliato apice ad $1.8 \mathrm{~mm}$. diametro; staminibus medio tubi affixis; calyce subanthesi $1.5-2 \mathrm{~mm}$. longo $0.3-1.5 \mathrm{~mm}$. longe pedicellato sparse strigoso, lobis obovatis $1.7 \mathrm{~mm}$. longis $0.3-0.4 \mathrm{~mm}$. latis apice rotundis; calyce fructiferi $2 \mathrm{~mm}$. longo ad $6 \mathrm{~mm}$. longe pedicellato, lobis laxe 
adscendentibus $0.4-0.6 \mathrm{~mm}$. latis obtusis; nuculis acute angulatis 4 tetrahedraeis haud pedicellatis glabris laevibus, angulo adaxiale ca. $1 \mathrm{~mm}$. longo, facie superiori margine angustissime alato circumdata; stigmate nuculis breviter sed distincte superanti.

SZECHUAN: Nanchuan Hsien, roadside, 8000-9000 ft., fl. white, May 25, 1928, W. P. Fang 915 (G); Nanchuan Hsien, roadside, 8000-9000, herb 1-1.5 ft. tall, fl. pale blue. May 31, 1928, W. P. Fang 1159 (G); roadside, 5000-6000 ft., herb $1 \mathrm{ft}$. tall, fl. pale blue, June 1, 1928, W. P. Fang 1348 (TYPE, Gray Herb.).

This plant of southeastern Szechuan is most closely related to $T$. floribunda of western Szechuan and western Kwangsi. It differs in having a larger corolla with an ampliate rather than cylindrical tube, a protruding style, broader and shorter calyx-lobes, and different nutlets. The mature calyx, unlike that of $T$. floribunda, does not have a noticeably thickened base covered with mineralized epidermis, nor does it develop a short but distinct cupulate tube. In the fruit the upper faces of the nutlets slope away from one another much less steeply than those of $T$. laxa. In $T$. floribunda, but not in $T$. laxa, the corners of the upper nutlet face are characteristically up-curving. The margin about the upper nutlet face in $T$. laxa tends to become very narrowly winged on the side opposite the nutlet apex. In T. floribunda the nutlet angles are acute and with a suggestion of a wing, but the latter is not so pronounced as in T. laxa. The relationship between the two species is very clear, but the two are certainly distinct.

Microula blepharolepis (Maxim.), comb. nov.

Omphalodes blepharolepis Maxim. Bull. Acad. St. Petersbourgh ser. 3, 27: 504 (1881) and Mel. Biol. 11: 269 (1881); Brand, Pflanzenr. Heft 78; 105 (1921).

Microula diffusa (Maxim.), comb. nov.

Omphalodes diffusa Maxim. Bull. Acad. St. Petersbourgh ser. 3, 27: 504 (1881) and Mel. Biol. 11: 270 (1881); Brand, Pflanzenr. 78: 106 (1921).

I am indebted to Prof. W. Th. Kuprevicz, Director of the Komarov Botanical Institute, Leningrad, for the great privilege of examining the types of Omphalodes blepharolepis and O. diffusa. These species, based on material from western China, in the region south and southwest of Lake Kokonor, are very definitely members of Microula, a genus well developed in the area of Lake Kokonor south into Yunnan. In technical characters and general appearance they are obviously members of Microula. Both species are well marked and distinct from any heretofore seen by me.

\section{Cryptantha Weberi, sp. nov.}

Planta perennis caespitosa pallida e radice palari oriens caudice denso humili multicipitali proferens; caulibus numerosis erectis foliosis 10-18 cm. longis supra medium floriferis, plus minusve hispidis (pilis 
patentibus 1-2 mm. longis) et abundanter hispidulo-villulosis (pilulis $0.2-0.3 \mathrm{~mm}$. longis saepe retrorso-adpressis); foliis pallidis numerosis abundanter hispidulo-villulosis (pilulis adpressis $0.1-0.3 \mathrm{~mm}$. longis) et hispidis (pilis 1-2.5 mm. longis basi incrassato orientibus adpressis vel praesertim secus marginem laminae adscendentibus vel rare patentibus) anguste oblanceolatis apicem versus latioribus firmis inconspicue costatis margine vix revolutis apice rotundis obtusisve; foliis basalibus confertis tempore florendi vigentibus $3-8 \mathrm{~cm}$. longis $3-7 \mathrm{~mm}$. latis; foliis caulinis numerosis medionalibus eis basalibus similibus sed minoribus $2-3 \mathrm{~cm}$. longis $2-4 \mathrm{~mm}$. latis; foliis supra medium caulis cymis axillaribus breviter pedunculatis suffultis; inflorescentia cylindrica infra medium bracteis exsertis donata, juventate densa $1.5-2 \mathrm{~cm}$. crassa 4-6 cm. longa, maturitate plus minusve interrupta $2-2.5 \mathrm{~cm}$. crassa $8-10 \mathrm{~cm}$. longa; cymis abundantibus sub anthesi glomeratis 5-8 mm. longis, fructiferis 10-15 mm. longis; calycibus ad anthesim 3-4 mm. longis , fructiferis $5-6 \mathrm{~mm}$. longis, $0-8 \mathrm{~mm}$. longe pedicellatis, lobis basi $0.7-1 \mathrm{~mm}$. latis sursum angustatis, inconspicue costatis sparse hispidis (pilis ca. $1 \mathrm{~mm}$. longis) et dense hispidulo-villulosis apice rotundis; corolla alba, tubo cylindrico $3 \mathrm{~mm}$. longo ad $2 \mathrm{~mm}$. crasso, lobis suborbicularibus 2-2.5 mm. diametro, limbo 4-6 mm. diametro; staminibus supra medium tubo corollae $(0.5-0.7 \mathrm{~mm}$. infra faucem) affixis; stylo cum gynobasi $3.5-4 \mathrm{~mm}$. longo; stylo $1.5-1.8 \mathrm{~mm}$. longo; nuculis $2-2.3 \mathrm{~mm}$. longis $1.3-1.8 \mathrm{~mm}$. latis ovatis fere symmetricis compressis angustissime marginatis, ventre sublaevibus sulcatis (sulco aperto anguste cuneato ad $0.5 \mathrm{~mm}$. infra apicem nuculae attingentibus), dorse tuberculis et rugis brevibus irregularibus plus minusve transversis sparse donatis.

COLORADO (Saguache County): along road to Stone Cellar Ranger Station and Saguache Park, near junction of main highway, 4 miles west of Cochetopa Pass, volcanic ash deposit, $9700 \mathrm{ft}$, with Aster coloradensis, Senecio Hallii and Penstemon secundiflorus, July 28, 1950, William A. Weber 5778 (TYPE, Gray Herb.) ; dry knoll one mile north of Stone Cellar Ranger Station, $9000 \mathrm{ft}$., July 7, 1936, Reed C. Rollins 1323 (G); Carnero Ranger Station, Cochetopa Forest, scattered on lower slopes, $10000 \mathrm{ft} .$, June 20, 1922, C. E. Taylor 573 (G).

A very well marked species of the mountains of south central Colorado for which I can suggest no close relative. In Payson's revision of Cryptantha § Oreocarya, Ann. Missouri Bot. Gard. 14: 239, 240 (1927), it keys out to C. virgata. In Brand's treatment, Pflanzenr. Heft 97: 79 (1931), it keys out to O. rugulosa. The caespitose and perennial habit, different indument and smaller nutlets with open scar all readily distinguish it from the very different $C$. virgata. Cryptantha rugulosa shows greater similarity with $C$. Weberi but differs in indument, in the cylindric thyrse of short cymes, small nutlets, etc.

Two flowering collections of the species have been known for over ten years. Though recognized as representing what was evidently an unnamed plant, they have not been used in describing the species, since 
they lack fruit. For at last receiving material of the plant in mature state I am indebted to Professor William A. Weber, of the University of Colorado, who made a special visit to the mountains of Saguache County in search of it. It is with great pleasure that I associate his name with the species.

\section{Craniospermum mongolicum, sp. nov.}

Herba humilis multicaulis ut videtur perennis et $5-6 \mathrm{~cm}$. alta; caulibus hornotinis $6 \mathrm{~cm}$. longis infra medium simplicibus supra medium cymas brevipedunculatas axillares dense dispositis proferentibus sparse hispidis (pilis patentibus vel adscendentibus 1-2 mm. longis) et hispidulis (pilulis $0.4-0.8 \mathrm{~mm}$. longis retrorse adpressis); foliis firmis enervatis villuloso-hispidulis (pilulis saepe retrorse adpressis $0.3-0.9$ $\mathrm{mm}$. longis vix abundantibus) et sparse hispidulis (pilis rigidis e basibus pallidis incrassatis prominulis erumpentibus facie superiore et praesertim margine laminae folii gestis) foliis basalibus congestis tempore florendi marcidis oblanceolatis 1-2 mm. latis $8-11 \mathrm{~mm}$. longis; foliis caulinis oblanceolatis $15-20 \mathrm{~mm}$. longis $3-4 \mathrm{~mm}$. latis apice acutis obtusisve; calyce 5-partito hispidulo sub anthesi $5 \mathrm{~mm}$. longo $\operatorname{mox}$ ad $8 \mathrm{~mm}$. longo, lobis subaequalibus oblongo-lanceolatis apice obtusis pedicello ad $1 \mathrm{~mm}$. longo; corolla ca. $7.5 \mathrm{~mm}$. longa glaberrima, tubo cylindrico $2.5 \mathrm{~mm}$. crasso, faucibus $2 \mathrm{~mm}$. longis apice $4 \mathrm{~mm}$. crassis, lobis caerulescentibus adscendentibus nervatis $1.5 \mathrm{~mm}$. longis a basi ca. $1.5 \mathrm{~mm}$. lato sursum laeviter attenuatis apice rotundis; staminibus basim versus faucis (ca. $4 \mathrm{~mm}$. supra basin corollae) affixis e plicis intrusis extus foveolatis orientibus glaberrimis; filamentis $5-6$ $\mathrm{mm}$. longis e fauce corollae $3-4 \mathrm{~mm}$. longe exsertis ligulato-linearibus basin versus aliquantum ampliatis basi imo geniculatis; antheris $0.5-$ $1.2 \mathrm{~mm}$. longis; stylo filiformi glabro longe exserto; nuculis maturis homomorphis $3.5 \mathrm{~mm}$. longis cinereis minute verrucosis sparse tuberculatis, dorse supra medium foveola conspicua donatis.

OUTER MONGOLjA: Daying Gol, dry hills at $5500 \mathrm{ft}$. alt., 1925, R. W. Chaney 195 (Type, Gray Herb.).

From the other members of the genus this well-marked species differs in having a low compact growth habit, hispid or hispidulous rather than villous indument, and a branched inflorescence. Furthermore, its filaments are not entirely linear nor do they arise directly from the walls of the corolla. They are broadened towards their geniculate base and each arises from a small protuberance situated low in the corolla throat. On the outside of the corolla the location of each filamentbearing protuberance is marked by a small but distinct depression. The plant appears to have a perennial root. From it arise a number of short stems about $6 \mathrm{~cm}$. long. These stems bear not only terminal cymes but also numerous, equally well developed lateral ones from the four to six axils above its middle. The inflorescence is obviously compound. It is dense, $2.5-3.5 \mathrm{~cm}$. long, and the most conspicuous part of the plant. In other species the inflorescence consists of a solitary 
subcapitate glomerule borne terminal on each stem. These stems are better developed than those in $C$. mongolicum and are more elongate and very much more leafy. In the most recent account of Craniospermum, Pflanzenr. Heft 97: 102-3 (1931), Brand recognizes three members of the genus, $C$. canescens DC., C. subvillosum Lehm., and C. subfloccosum Krylow. All these are closely related, so closely in fact that they may be no more than forms of a single somewhat variable species. They grow in southern Siberia along the Mongolian border from the west of the Altai east to beyond Lake Baical. The proposed new species is more southerly, occurring along the southern extension of the Altai in western Outer Mongolia. The type was obtained at Daying (or Da-Ying) Gol, a stream heading in the Baga Bogdo Range and flowing north into Tsagan Nor, about long. $101^{\circ} 30^{\prime}$ and lat. $45^{\circ} 5^{\prime}$. It was distributed misidentified as "Arnebia guttata."

Trichodesma calycosum Collett \& Hemsl., Jour. Linn. Soc. Bot. 28: 92 (1890) ; Lacaita, Jour. Linn. Soc. Bot. 43: 476 (1916) — type from Burma; "Shan hills at 4000 feet."

Lacaitaea calycosa (Coll. \& Hemsl.) Brand, in Fedde Repert. 13: 81 (1914) and Pflanzenr. Heft 87: 44 (1921).

Trichodesma Hemsleyana Levl. in Fedde, Repert. 9: 327 (1911) and Fl. Kouy Tcheou 55 (1814); Brand, Pflanzenr. Heft 78: 43 (1921) - type from "Kouy-Tcheou [Kweichow, China], J. Esquirol 745."

Trichodesma sinicum Brand in Fedde, Repert. 12: 504 (1913) and Pflanzenr. Heft 78: 43 (1921) - type from Szemao, southern Yunnan, Henry $10124 \mathrm{D}$.

Trichodesma calcareum Craib, Kew Bull. 1914: 8 (1914) - type from northern Siam, "Doi Chieng Dao, crevices of limestone rock, $900 \mathrm{~m}$., Kerr 2856."

Trichodesma khasianum var. calcareum (Craib) Brand, Pflanzenr. Heft 78: 33 (1921).

Octosomatium Kerrii Gagnep. Not. Syst. 14: 23 (1950) - type from Laos, Indo-China; Muong-Khao, Xieng-Khouang dist., ca. lat. $19^{\circ} 50^{\prime}$ and long. $103^{\circ} 30^{\prime}$, Kerr 20978 .

Known from Burma (north of lat. 22 ${ }^{\circ}$ ) and from China (western and southern Yunnan; Kweichow) south to about lat. $19^{\circ}$ in northern Siam and adjoining Indo-China; also in Sikkim.

BURMA: Kanpetlet, Chin Hills, 7500 ft., hillside, fairly common, shrub $15 \mathrm{ft}$. tall, trunk 3 in. thick breast-high, fl. white, F. G. Dickason 8425 (A); Webula (Falam), damp ravines and open mountain slope at $4000 \mathrm{ft}$., fairly common, shrub 8-10 ft. tall, Dickason 7347.

INDO-CHINA: Muong-Khao, Xieng-Khouang, Laos, Kerr 20978 (Paris, TYPE of $O$. Kerrii; fragment received on loan).

CHINA: Y un nan: Salween Vallev, lat. $25^{\circ} 6^{\prime}$, in open scrub at $4000 \mathrm{ft}$. , shrub $20 \mathrm{ft}$. tall, Forrest 13665 (A) ; Salween Vallev, lat. $25^{\circ} 10^{\prime}$, long. $98^{\circ} 50^{\prime}$, open dry situations on margin of scrub, half shrubby plant 3-4 ft. tall, Forrest 19341 (A) ; Lan-Tsang Hsien, $1100 \mathrm{~m}$. alt., woody plant on mountain slope, $C$. W. Wang 79127 (A); Mengtse, $5000 \mathrm{ft}$. alt., shrub $3 \mathrm{ft}$. tall, fl. 
white, A. Henry 10124 (A, NY); Lunan, shrub 5 ft. tall, fl. white, Henry $10124 A$ (A, NY) ; Chu-yuan, shrub 3 ft. tall, Henry $10124 B$ (A, NY); Red River Valley, Manpan, $4000 \mathrm{ft}$., shrub $4 \mathrm{ft}$., fl. white, Henry $10124 \mathrm{C}$ (A); Szemao, $5000 \mathrm{ft}$., shrub $10 \mathrm{ft}$. tall, fl. white, Henry 10124D (A, ISOTYPE of $T$. sinicum). K wei chow : Lo fou, Feb. 1909, J. Cavalerie 3498 (G); without locality, J. Esquirol 745 (G, photo \& frag., TYPE of T. Hemsleyana).

A study of the recently published Octosomatium Kerrii Gagnep. reveals it to be a synonym of the present plant, which now has accumulated four different trivial names and has twice been made the type of a monotypic genus, i.e. Lacaitaea Brand and Octosomatium Gagnep. It is a large shrubby plant with broad opposite leaves, which grows 1-6 m. tall and has fruit and flowers characteristic of Trichodesma in all details save only for the 8-10 gibbose intrusions developed in the corolla throat. Unlike most congeners it is not a desert or steppe plant but rather an inhabitant of the tropical forest.

The invaginate appendages present in the corolla throat of $T$. calycosum are of special interest. No other member of the genus has similar appendages, and furthermore, no other member of the entire Boraginaceae has them in so large a number. The corolla of $T$. calycosum, though usually pentamerous, is occasionally tetramerous and bears two gibbose appendages in the throat opposite each corollalobe. In other Boraginaceae the faucal appendages are traversed medially by the primary vein leading to the corolla-lobe and accordingly occur singly in the throat opposite the middle of the lobe. In $T$. calycosum the two appendages opposite each lobe arise lateral to the vein which courses between them. The condition, though unique in the family, is readily homologized. Many of the Boraginaceae with welldeveloped faucal invaginations have the invagination more or less strongly retuse at the summit. The vein leading to the corolla-lobe is detoured over the summit of the invaginate appendage. In those appendages that are lobed or emarginate at the summit its course over the summit lies at the bottom of the apical sinus. Should the appendage become strongly bilobed or parted, the vein would have no detour and would pass directly between the halves of the appendage, which would then appear double. The supernumerary appendages of $T$. calycosum probably had some such origin.

It is interesting to speculate why double faucal appendages should have developed only in this species of Trichodesma. The genus is a member of the Cynoglosseae, the most highly evolved tribe in the Boraginaceae, in which faucal appendages are usually well developed. Their loss in Trichodesma is probably associated with the elaboration of the androecium, in which the large anthers, held together by twisted tips, form a large protruding cone that controls all access to the corolla-tube. Faucal appendages, alternating with the anthers, would hinder rather than guide the proboscis of an insect seeking the slit between the closely juxtaposed anthers. This is obviated by the divided 
faucal appendages of $T$. calycosum. In that species they probably represent a modification and persistence of an ancestral character. As a general rule, in any large natural group such as Trichodesma, ancestral characteristics are more frequently retained by the shrubby or arborescent than by the herbaceous members. The latter, with a short life history and more frequent generations, can be expected to vary more rapidly and so deviate more from the ancestral than do the woody and arborescent congeners. Significantly, T. calycosum is the most robust member of the genus, and with the possible exception of T. khasianum Clarke, the only large shrub in the genus. The normal single faucal appendages of the Cynoglosseae having no function and being perhaps even disadvantageous in the Trichodesma flower, have been eliminated in most species of the genus. In T. calycosum, divided and so no longer hindering insects seeking the nectaries at the bottom of the floral cup, the appendages appear to have persisted as nonfunctional innocuous structures not yet eliminated in the course of evolution.

Brand states frankly that $T$. calycosum, though admittedly otherwise typical of Trichodesma, should, because of its faucal appendages, be segregated to form the monotypic genus Lacaitaea. Gagnepain, in establishing the synonymous genus Octosomatium, gives no intimation that he recognized the obvious affinities of the plant with Trichodesma. He considered the plant remarkable because of its opposite leaves, the prominent line on the stem joining the attachments of opposing leaves, the tetramerous flowers (of his specimen), and finally, the double faucal appendages of the corolla. Of the characters mentioned by him only the faucal appendages are notable when the plant is compared with Trichodesma. They alone are distinctive of T. calycosum and they alone constitute the only character of possible generic value that can possibly justify any proposal that the species be given special recognition as representing a monotypic genus distinct from Trichodesma.

In estimating the importance to be placed on the faucal appendages of $T$. calycosum, I am influenced by the remarkable similarity existing between that species and T. khasianum. The latter ranges just west of T. calycosum and like it is a shrub of monsoonal forests. Trichodesma khasianum has absolutely no faucal appendages, has less hairy anthers, and usually has more conspicuously white-dotted upper leafsurfaces, but except for these differences the two species are extremely alike, so much so that any doubt as to their extremely close relationship is inconceivable. These two species belong together in one and the same genus! To disassociate them generically on the basis of one character is arbitrary and unnatural. I am, accordingly, content to assign T. calycosum as well as T. khasianum to Trichodesma $\S$ Friedrichsthalia, a section containing several African species which also have ample opposite leaves combined with frutescent habit. 
Trichodesma calycosum var. formosanum (Matsumura), comb. nov.

Trichodesma formosana Matsumura, Bot. Mag. Tokyo 12: 108 (1898) "Hab. Formosa: in montosis ad Taichu (Y. Tashiro, no. 35) ; Tenkachilaisha, Shu-shu-kai (C. Owatari)."

Trichodesma khasianum sensu auct. Formos.; S. Sasaki [Cat. Govt. Herb.] Dept. Forestry, Taihoku, Formosa, Report 9: 431 (1930); D. Hou, Taiwania 1: 212 (1950).

FORMOSA: Kinkwaseki, T. Ito (A, photo); South Cape, A. Henry 286 \& 939 (A) ; Boryo to Kuraru, prov. Koshun, south Formosan common shrub 3-6 ft. tall, fl. blue, E. H. Wilson 11014 (A); prov. Nanto, low altitudes, common bush, 6-12 ft. tall, Wilson 9831 (A); [Bankinsing], Henry 1239 (NY); Taito-cho, Shikano, 1931, Tanaka 10462 (NY).

This plant of Formosa has been reported numerous times as "Trichodesma khasianum." Actually it is scarcely separable from T. calycosum. Indeed, it is distinguishable only by the arrangement of hairs on the back of the anthers. In the plant of Formosa these hairs are appressed and have the appearance of having been combed in different directions, left and right, from the mid-line of the anther. The hairs of the anthers of the continental plant are less appressed and do not have the combed, orderly appearance. The difference is a minor one, and only because it seems to be geographically correlated does it merit nomenclatorial recognition.

Arnold Arboretum,

Harvard University. 


\section{$2 \mathrm{BHL}$ Biodiversity Heritage Library}

Johnston, Ivan M. 1952. "Studies in the Boraginaceae, XXII. Noteworthy species, chiefly Asian and South American." Journal of the Arnold Arboretum 33(1), 62-78. https://doi.org/10.5962/bhl.part.29332.

View This Item Online: https://www.biodiversitylibrary.org/item/33609

DOI: https://doi.org/10.5962/bhl.part.29332

Permalink: https://www.biodiversitylibrary.org/partpdf/29332

\section{Holding Institution}

Missouri Botanical Garden, Peter H. Raven Library

\section{Sponsored by}

Missouri Botanical Garden

\section{Copyright \& Reuse}

Copyright Status: In copyright. Digitized with the permission of the rights holder.

Rights Holder: Arnold Arboretum of Harvard University

License: http://creativecommons.org/licenses/by-nc-sa/3.0/

Rights: https://biodiversitylibrary.org/permissions

This document was created from content at the Biodiversity Heritage Library, the world's largest open access digital library for biodiversity literature and archives. Visit BHL at https://www.biodiversitylibrary.org. 